\title{
Polish education system under 2017 reform: Assumptions, aims and controversies
}

\author{
Justyna Wojniak $^{1, *}$, and Marta Majorek $^{2}$ \\ ${ }^{1}$ Pedagogical University of Krakow, Podchorążych 2, 30-084 Kraków, Poland \\ ${ }^{2}$ Andrzej Frycz Modrzewski Krakow University, Herlinga - Grudzińskiego 1, Kraków 30-705, \\ Poland
}

\begin{abstract}
The paper analyzes some current changes in the Polish education system. The comprehensive reform of the system was undertaken in 2016, and the new system was introduced in the school year 2016/2017, changing the structure of the education cycle as well as the teaching content and the handbooks. The aim of the Ministry of National Education was to create a "good school" for students, teachers and parents. The reform, however, triggered a national discussion on its aims and assumptions, as it is accompanied by a number of controversies and strong differences of opinions in the Polish society.
\end{abstract}

Keywords: Education system, education reform, Poland

\section{Introduction}

Current discussion around the reform of Polish education system has proven a visible split of the opinions concerning the idea of such a profound change of the school life, not only among the politicians, but in the general public opinion as well. First of all, controversies have aroused around the aim of the reform itself. Before the reform, the Polish education system had been assumed as an effective one according to a number of surveys and research. Moreover, the pace of introducing such fundamental changes was also quite short, which demanded a lot of organizational and financial efforts taken particularly by the local authorities which are responsible for effective performance of educational institutions in Poland. Even though the first school year under the new educational provisions has already finished, the controversies still exist and the discussion on the reform is quite lively, and it is not only within the groups of parents or teachers who are at the center of the transformation. The public opinion in Poland demonstrates a visible split in the points of view on this matter, which is strongly connected with their political attitudes towards the government.

\section{On the verge of the reform - reasons of the change}

According to the official information published on the Ministry of National Education website: "The developed reform of education meets the expectations of the majority of

\footnotetext{
*Corresponding author's e-mail: justyna.wojniak@up.krakow.pl
} 
Poles who want a modern school, and at the same time one that is strongly rooted in our tradition. The changes are well-thought and have been planned for numerous years. It is important to us that every student, regardless of their origin and the material status of their parents, has a good school and good education. The reform of education is not just a change in the school system. It is also a proposal of new solutions in the development of vocational education strongly linked to the labor market and changes in the organization and functioning of schools and educational institutions" [1].

\subsection{Key features of the new education system}

The reform of education in question was introduced at the beginning of 2017. Its main objective is to prepare the students who complete the entire education cycle to meet the needs of individual development and those of a modern labor market, which requires some solid grounds in a form of general education.

The key elements of the reform are as follows:

- Change in the structure of the education system consisting in the introduction of a long 8-grade school (primary and four-year high school and five-year technical high school).

- The obligation for a one-year pre-school preparation for 6-year-olds, when the child learns some basic skills - its teaching, like learning at school, is covered by an educational subvention from the state budget.

- Providing free textbooks.

- Strengthening the general and vocational education in secondary schools by extending the learning cycle by one year.

- Introduction of a 3-year branch education (1 qualification in a given profession) with the possibility of acquiring further qualifications and preparation for the matriculation exam in a 2-year second-degree industry school.

- Propagation of a dual education implemented in cooperation with entrepreneurs.

- Increasing the participation of employers in co-financing the vocational education by establishing the Fund for Development of Vocational Education [2].

The changes entered into force in the 2017/2018 school year. Students completing the 6th grade of primary school in the 2016/2017 school year became students of the 7 th grade of a primary school. Structural changes are introduced pursuant to the Act of 14 December 2016 on "Law on School Education" and the Act on "Legislation introducing the Act - Law on School Education" of the same date.

The target structure of education will include:

- 8-year primary school;

- 4-year general high school;

- 5-year technical college;

- 3-year industry school of the first degree;

- 2-year industry school of the second degree;

- 3-year special training school for work;

- Post-secondary school.

The industry-oriented primary school replaced the basic vocational school on 1 September 2017. The second-cycle industry school for graduates of the industry-first school will be introduced as of the school year 2020/2021. Compulsory education is 10 years in Poland and includes the last year of the pre-school education, a 6-year primary school and a 3-year junior high school. As regards the education system's reform adopted in 2017, compulsory education is 9 years now and covers the last year of pre-school education and 
an 8-year primary school. The schooling obligation and the obligation to learn were separated in the Polish education system. The schooling obligation (i.e. the obligation to attend primary and lower secondary school, in a new structure covering the 8-year primary school) is imposed on children and juveniles aged 7-16 (in the new structure they are 7-15 years old). The compulsory education applies to young people aged 16-18 (15-18 years old in a new structure) and the duty can be fulfilled in a school or out-of-school form (implementation of professional training at the employer's) [3].

\subsection{Structure of the national compulsory education system}

\subsubsection{Early education and care}

Facilities for children aged 0-3:

- Nurseries,

- Children's clubs.

There is no obligation to attend nurseries. They are not a part of the education system but are governed by The Ministry of Family, Labor and Social Policy.

Facilities for children aged 3-6:

- Kindergartens,

- Pre-school departments in primary schools,

- Pre-school education teams,

- Pre-school points.

Pre-school education has been optional for children aged 3-5 and obligatory for 6-yearolds since September 2016. Every 4- and 5-year-old is entitled to a place in kindergarten. From September 2017, this right have also applied to 3-year-old children. From the 2016/17 school year, parents of 6-year-olds have the right to choose - they can send a 6-year-old to the 1st grade of primary school or allow to continue its education in a pre-school education center. 7-year-old children begin compulsory education from the 1st class of primary school.

Basic education

Prior to the reform, education had been carried out in 6-year compulsory primary schools for pupils aged 6/7-13.

Education included two stages:

- Classes 1-3 (early school education),

- Grades 4-6, where the teaching is divided into subjects.

At the end of the primary school there was an external test conducted, bearing solely an informative function.

After the reform

The reform consists of introducing a single-structure comprising of ISCED 1 and ISCED 2 levels (primary and lower secondary education). It is an 8-year primary school for pupils aged 6/7 to 15 years. Learning in an 8-year primary school includes two stages:

- Classes 1-3 (early school education),

- Grades 4-8, where teaching is divided into subjects [4].

\subsubsection{Lower secondary education}

Before the reform, the education had been carried out in obligatory 3-year gymnasiums (youth aged 13-16). At the end of the gymnasium, an external exam was conducted, the results of which decided on admission to upper secondary schools. 
After the reform

From 2017, gymnasiums have been gradually eliminated from the system. Students completing their studies in the 6th grade of an elementary school become students of the 7 th grade of the new 8-year primary school. From the school year 2018/19, the obligatory external examination will take place in the 8th grade of primary school.

\subsubsection{Secondary education}

The vast majority of junior high school graduates continue their education in upper secondary general or vocational schools, although it is not compulsory (students are only subject to the schooling obligation, however it ceases to apply after the student turns 18).

This stage includes learning in the following types of schools:

- 3-year general secondary schools,

- 4-year technical upper secondary school,

- 3-year basic vocational schools.

Secondary school is attended by young people aged 16-19 (16-20 years old in the case of technical secondary schools).

After the reform

The reform of lower secondary schools will begin in the 2019/2020 and end in the 2023/2024 school year.

New types of secondary (secondary) schools:

- 4-year general high school,

- 5-year technical upper secondary school,

- 3-year industry school (1st degree) (it has been operating since September 2017),

- 2-year industry school (second cycle),

Students of the 1st level trade school (before the reform of the main vocational school) and the technical school may take confirmation exams during or after their graduation qualifications in a given profession and obtain a diploma confirming their professional qualifications. High school and technical high school students can take an external matriculation examination after finishing the school. It allows to obtain a matriculation certificate, which is a prerequisite for admission to higher education schools. Students from the second-level industry school will also have this option [5].

\subsubsection{Post-secondary education}

This stage of education is covered by the secondary education in the Polish education system. Post-secondary schools are intended for people with general secondary education and offer a diploma confirming professional qualifications provided that the student passes the exam. The course of post-secondary education is from 1 to 2.5 years. The postsecondary school students sit the same vocational examinations as students of basic vocational and technical schools. Post-secondary schools are not subject to any structural changes due to the reform [6].

\section{Discussion}

The Constitution of The Republic of Poland, adopted by the National Assembly on 2 April 21997 provides for regulations related to the education. It guarantees the right to learn, but at the same time it imposed the schooling obligation until the age of 18 . The Constitution confirms that education in public schools is free of any charges. Parents have the freedom 
to choose other than public schools for their children and are entitled to establish such facilities. At the same time, the Constitution stipulates that all citizens are guaranteed with universal and equal access to education [7]. For this purpose, public authorities are obliged to create and support systems of individual financial aid for pupils and students.

According to the assumptions made by the educational transformation, it is indispensable to achieve the following goals:

- Raising the level of public education through propagation of the secondary and higher education;

- Equalizing educational opportunities;

- Encouraging the improvement of the educational quality, understood as an integral process of upbringing and education [8].

Therefore, the reform of education was carried out among others to meet the postulate of equalizing educational opportunities. It was recognized that the pre-reform school was not conducive to achieving equality in this area, and education was not of egalitarian character [9]. The system of education functioning before 1999, in the opinion of the reformers, was elitist or even exclusive. The low participation of young people who obtained secondary and higher education was indicated in order to confirm that argument. It was noted that secondary school and higher education were primarily available for students coming from families of a high social status [10].

The changes introduced by the latest reform may have a negative impact on the equalization of opportunities. First of all, we are talking about shortening the schooling obligation by one year, and also about withdrawing from the idea of an earlier education obligation for the youngest children. Five-year-old children covered by the educational obligation, who reach the nets and kindergartens, benefit the most. The earliest possible inclusion of a child into the education system is extremely important. Unfortunately, these chances have been taken away from them. Under the influence of social protests, 5-year-old children were excluded from the school duty. Unfortunately, the rejection of equalizing educational opportunities in the pre-school age can be never made up. Meanwhile, research confirms that each additional year in the kindergarten improves results in mathematics. It is then that shaping of competences takes place at a later age [11].

Children from the age of seven have been required to attend school from the 2016/2017 school year. A 6-year-old child have the right to start education in the first grade of primary school if he / she has benefited from pre-school education in the school year preceding the school year in which he or she is to start the school. If a 6-year-old did not attend a kindergarten, the parents are still able to enroll their child in the first grade. In this case, however, it will be necessary to consult the psychological and pedagogical specialist about the possibility of beginning the primary school education [12].

It follows that parents who want to send a 6-year-old child to the primary school will encounter a number of problems, which in turn will lead to a shift in the school-leaving age. The European Union also encourages parents to send their children to kindergarten and school as early as possible. In 2011, the European Commission created the document entitled "Early Childhood Education and Care: we will guarantee all children in the EU a good start in the future." The authors emphasize that "early education and childcare is the foundation for successful lifelong learning, social integration and personal development, and at a later stage - a factor that increases employability"[13].

There is a tendency in the European Union to lower the age at which the compulsory education begins. Several countries have decided to do so, and the last pre-school class became the first class of primary school. It could be stated that Poland took the same path. Five other EU member states reduced the age of starting compulsory education, apart from Poland. In Romania, not seven-year-old but six-year-old children go to school, however, in Slovenia the last grade of kindergarten was transferred to schools. In Greece, Cyprus and 
Latvia, primary education has not changed, but the compulsory pre-school education now starts one year, a year and four months and two years earlier respectively [14]. In the light of the change which was carried out in 2016, the possibility of early education of children was basically withdrawn. The regulations indicate that children will have the guaranteed pre-school education from the age of 3 , which is not feasible in the current circumstances. The problem is the availability of the pre-school education. Poland suffers from a deficit in the number of kindergartens and the state does not guarantee that 3-year-old children will be able to begin their education. This will have some measurable impact on the careers of active mothers who will be excluded from the labor market for the period of childcare, as they will not have a possibility to send their children to kindergartens. What is more, it is well-known that a long break in the professional activity evidently practically results in eliminating an employee (in this case a mother) from the labor market.

Junior high schools and in general the whole Polish education system is not perfect - no one has created such a system in the world so far. However, the collected data suggest that the introduction of junior high school in 1999 was an idea that brought more good than harm. Although some people may find it surprising, gymnasium is the strongest element of Polish education. This is the result of all available research - both Polish and international. Before the introduction of junior high schools, we had over $80 \%$ of students who did not cope with reading comprehension in vocational schools. They were simply functional illiterates. After the reform, we gradually improved these results until we reached the top in the OECD. Now we have, for example, more good students in mathematics than Finland, famous for its education system [15]. PISA (international survey of skills of 15-year-olds) and PIAAC (International Adult Competence Research) show that young Poles are really well-educated [16]. Polish students between 16 and 19 years of age have several points more than the average for the OECD countries in reading comprehension, and they reach this average in mathematics. The younger colleagues examined in the PISA study achieved even better results. The output is also quite good for 16-24-year-old students. Only the elders - those who did not graduate from gymnasiums, only 8-year primary school - lower these results [17]. Currently, we are dealing with the notorious undermining of the results of the above-mentioned research - mainly the PISA surveys - by the governing party politicians. It is the largest measurement of students' skills in the world in three basic areas: reading and interpretation, mathematics and reasoning in natural sciences, developed by an international consortium of the best OECD experts [18]. Of course, it can be argued that it does not include knowledge of religion, history and Polish literature, but these are not the key skills to succeed in international competition.

One of the most repeated arguments of the reformers is that the middle school is the breeding ground of the worst youth pathology. A deep analysis performed by the Institute for Educational Research, based on several both domestic and international studies, gave quite different results. According to estimates, bullying affects about 10 percent of Polish students [19]. As verified in the HBSC study in the 2009/2010 school year, the victims of bullying (those bullied at least two-three times a month in the last few months) accounted for around 14\% among 11-year-old, 11\% among 13-year-old and 7\% among 15-year-old students. The scale of bullying in Polish schools is average when compared to almost 40 countries or regions [20]. In addition, it is not true that it is getting worse. Research conducted in 1997, 2003 and 2007 indicates the stability or even a slight reduction in the scale of aggression and violence in schools. And what is most important, it is not so intense in junior high schools at all. The study entitled "School without Violence" conducted in 2011 shows, for example, that physical aggression was encountered by $49 \%$ of students in primary schools, $36 \%$ in junior high schools and 18\% in high school [21].

Concerning the industry schools, the communist authorities abolished lower secondary schools in 1948, justifying the reform with the need to quickly prepare professional 
personnel for the economy, and above all, with the industry which reported the demand for skilled workers - thus, two big economic plans were implemented in Poland at that time: 3 years at first (1947-1949) and 6 years afterwards (1950-1955) [22]. An element of the education reform introduced by the communists was the simultaneous expansion of vocational education - basic vocational schools with a duration of education from 2 to 3.5 years and a very narrow curriculum for teaching humanities and general subjects were introduced. There was also a technique with a 5-year learning cycle, where the emphasis was placed on vocational and specialist education, and vocational high schools oriented on preparing graduates directly for work [23]. Even if we sometimes miss a locksmith who would replace a door lock or a shoemaker who would repair our favorite shoes, skilled manual workers are less needed in the modern economy than they were in the era of rapid industrialization. And in a moment, along with the progressing automation, not only in industry but also in services, the demand for them will be even lower. This whole model from the past does not match the challenges of today's world thus, the workers are not any as busy twisting the devices on the belt, as they were a hundred years ago in Ford plants.

Introduction of junior high schools was guided by the idea of equal opportunities. The Minister of Education, Mirosław Handke, employed this level of education in 1999, wishing, among other things, to help children from poorer families, from neglected rural areas, with a lower socio-economic status. And research confirms that it has succeeded to a certain extend [24]. Michał Sitek states that from his own analyzes (carried out on the basis of PISA data) it appears that between 2000-2012 the differences in educational output were levelled, which was mainly due to the improvement in results achieved by the weakest students [25]. Differences between students with low and high socio-economic statuses have decreased, and so has the influence of social origin on the selection of upper secondary school. Equally, Hungarian researchers L. F. Drucker and D. Horn appreciated the equalization of opportunities by Polish junior high schools. Their report shows that equalizing opportunities by Polish junior high schools has a long-lasting effect. The lower secondary school reform in Poland improved the chances of graduates to find a job and influenced the increase in their remuneration. These effects occurred especially in the group of students achieving the lowest educational results [26]. An interesting problem arises here, why Polish lower secondary schools have helped the weakest students and low socioeconomic status. Many researchers associate this with the extension of one year of general education. A weakness of education systems which quickly select students is their large stratification. Children from poorer families, national minorities, children of less educated parents go to vocational schools - this is the case, for example, in Germany, and this problem was noticed by the Hungarians who transformed their post-communist educational system adopting the German model, and the y are now thinking about changing it again.

It is no coincidence that the above-mentioned PISA tests examine the students' skills related to reading comprehension, logical thinking, math and knowledge in the field of natural sciences. These are the skills that today are crucial for development of a modern and innovative economy, as the politicians like to say. Only by having these skills, can we successfully compete in the world. Will we continue to intensively develop and promote them in the new educational system, without lower secondary schools? There are some serious doubts. Elimination of the obligatory test of nature at the end of the primary school will cause, for example, a significant part of children to lose motivation to learn nature. There will also be very little IT teaching hours in the new high school program. On the other hand, there will be more teaching hours of history in all types of schools.

What is more, some serious doubts may arise from the form of preparing the reform, in particular the new core curriculum for the reformed school. Not only the negation of the previous reform, the lack of reliable arguments supporting the change of the system, but also the lack of reference to authorities in the field of education can be questionable from 
the perspective of the quality of changes. The Ombudsman joined the appeal proceedings in the case. He assessed that the Voivodeship Administrative Court correctly recognized that the experts who worked on the core curriculum for mathematics in the primary and general secondary schools are individuals holding public functions and contractors of the Ministry. This means that information about them is subject to disclosure under the Act on Access to Public Information. On 22 November 2017, the VAC in Warsaw (file reference number II $\mathrm{Sa} / \mathrm{Wa}$ 1094/17) quashed the two refusal decisions appealed by the Minister of National Education regarding the disclosure of public information. It was a question of the composition of a team of experts preparing a new core curriculum - related to the reform of education introduced on 1 September 2017; names of team members and information about their academic degrees and institutions which they are employed in. The resort referred to the protection of experts' privacy. In the opinion of the Ministry of National Education, they were not persons holding any public functions within the meaning of the Act on Access to Public Information. The Minister indicated that there is a contract concluded with those individuals. They also had no impact on the extent to which the materials they developed would be used in legislative work. In addition, the Ministry did not receive their statements about the resignation of their right to privacy protection. The Provincial Administrative Court ruled that the minister had committed a violation of law. This violation considered improper application of the restriction in access to public information - and thus violation of the rule of law. The court ruled that since these persons had influenced the shape of the adopted core curriculum to some extent, and thus the content of decisions of a general social nature, it is justified to treat them as holding public functions. The court stated that their data cannot be excluded due to privacy. The fact of concluding the civil law contracts with with those individuals additionally spoke for the necessity of disclosing their names and surnames. According to the court, in order to implement the constitutional principle of transparency of public administration activities and transparency of spending public funds, it is necessary to provide citizens with full knowledge of who - by concluding contracts with state authorities - becomes a beneficiary of public funds. It also makes it possible to assess whether the task was entrusted to persons with appropriate knowledge, and the contract itself was not in fact a camouflaged mean of unauthorized flow of public funds to private individuals. In its opinion, the conflict between the right to access public information should prevail over the right to the protection of personal data. As part of the market economy, there is no obligation to enter into contracts with public entities - the court highlighted. The Minister of Education filed an appeal to the Supreme Administrative Court. She allegedly violated the rules of the VAC, including by giving prevalence to the right to access public information. She also argued that the criterion of "a person holding public functions" is to have decision-making powers in the scope of the content of a normative act.

In the Ombudsman's opinion, who fully agrees with the verdict of the VAC, the complaints are unjustified. The court correctly claimed that persons working on the development of the core curriculum are individuals who hold public functions and contractors of the Ministry of National Education. The Ombudsman stressed that the VAC's findings are based on the wide-ranging understanding of the term "a person holding a public function" adopted in the case-law. It does not matter on what basis the person holds the public function. Undoubtedly, in the case of experts preparing the core curriculum, we are dealing with the decision-making dimension of their competence - as the Ombudsman, Adam Bodnar, wrote [27]. The Ombudsman claimed that these individuals were assigned to develop a new core curriculum, so they had some real (not only hypothetical) impact on the legal situation of other people. It is also impossible to accept the standpoint of the Ministry of Education that their work was of an advisory and consultative nature, since the body itself admitted that the experts prepared specific parts of the assumptions to the core. The 
principle of disclosure of personal data of the entities - parties to contracts concluded with public bodies and using public assets - is underlined in the currently uniform ruling system of the Supreme Administrative Court. Every contractor of a public authority which benefits from public funds is a person holding public functions. To the extent that the information refers to this relationship, they are subject to public disclosure [28].

Another issue worth pointing out is the huge cost of the changes implemented in the education system. Despite the assurances from the current authorities, it turns out that the majority of expenditures will be borne by local governments. Local governments submit applications to the Ministry of Education for reimbursement of costs incurred for education reform. For example, the authorities of Poznań stated that they had to contribute PLN 16 million from the local budget for this purpose. The local government in Łódź, in turn, speaks of over PLN 52 million. Anna Zalewska, the Minister of National Education, when asked about this issue, assured that the Ministry regularly allocates money to local governments. As "Rzeczpospolita" reported, the Ministry of National Education has received 1131 applications from local governments so far, demanding reimbursement of costs incurred prior to the education reform [29]. Local authorities complain that they had to use their own budgets to cover the costs of retrofitting classrooms or severance payable to the exempted teachers. Local government: the cost of reforming education is enormous. For example, the authorities of Poznań reported that they spent PLN 16 million, the local government of city of Gdańsk spoke about PLN 8 million, and the authorities of Łódź gave the amount of PLN 52.6 million [30].

A significant change concerns the teaching of children with different types of disabilities. So far, the integration of disabled children has been as close as possible, through the creation of integration classes and the implementation of various assumptions aimed at including this group of children in the general education system. In response, this is what the reformed system has to offer: shorter education of children with more severe disabilities, individual teaching of children with Asperger, only at home, a longer path to obtain a decision on special education. This is just a part of the consequences of the reform of education for parents of children with disabilities. Educational subsidies for students with autism, Asperger's syndrome and conjugate disabilities are 9.5 times higher than for a healthy student. Parents suspect that the government intends to lower subventions in search of savings and exclude the pupils with Asperger's syndrome from the group receiving the ruling on special education, which is significantly more expensive than education of a healthy student. As a result of the changes, children with various types of disabilities, especially those intellectual, would be eliminated from the inclusive educational processes carried out in groups. This may cause isolation and lack of social development, but it can also lead to reduction in the degree of tolerance from healthy students who will be deprived of contact with children with disabilities.

\section{Conclusion}

As the Polish school system has been working within the frames of new regulations for one school year, it is difficult to already assess its effectiveness or its strengths and weaknesses. The fact is that the way of introducing the reform, the dynamic pace of this process and a number of new regulations have triggered the discussion and certain controversies, particularly due to the insufficient consultations with the teachers' community, the groups of parents and the non-governmental organizations which are active in the field of education.

One of the main doubts over the change of the system structure was the notion of the extent, to which the previous system proved its lack of effectiveness or quality. The international surveys assessing the level of performance of Polish youth showed that there 
were no significant discrepancies between them and their peers from other countries. Moreover, the organizational matters, particularly those related to adaptation of the existing educational institutions to the demands of the reform - what is the responsibility of local governments - required an apparent financial effort, and the state support turned out to be insufficient. Hence, the local authorities decided to present their complaints on this matter to the Voivodeship Administrative Court.

The reform has also its impact on the teachers' situation. One of the most important assumptions concerning their career is the duration of their professional path. The new regulation makes this path longer than it was before the reform, as the period for gaining the second rank was extended by one year, and the elongation of the period of break between getting one rank and beginning the internship to the next level of professional promotion. It has also its impact on the teachers' salaries level. Another negative aspect of the change within the structure of the school system is a decreasing number of teachers. Plenty of them have lost their jobs and a significant number of those professionally active were forced to work in a part-time system. There is a noticeable number of teachers who have to combine employment in more than one educational institution in order to reach a satisfying level of income. For obvious reasons, this situation causes rising disappointment among the teachers, and the two main Polish teachers unions present their discontent with these provisions.

As it was emphasized above, it would be too early to make an attempt of an assessment the reform at the moment. However, it is worth bringing forward the main assumptions of this serious change together with the doubts and concerns that still exist in the Polish society after the first school year under the new regulations.

\section{References}

1. Ministry of National Education, $O$ reformie. Available at: http://reformaedukacji.men.gov.pl. (2018)

2. Eurydice, Krótka informacja o polskim systemie edukacji 2017/2018. Available at: http://eurydice.org.pl/wp-content/uploads/2017/10/System-edukacji-wPolsce_2017_2018_PL.pdf. (2017)

3. Dobra Szkoła. Reforma systemu edukacji. Struktura szkót. Available at: https://reformaedukacji.men.gov.pl (2017)

4. Eurydice, op. cit.

5. Ibid.

6. Ibid.

7. Constitution of The Republic of Poland. Article 70. Available at: http://www.sejm.gov.pl/prawo/konst/angielski/kon1.htm (1997).

8. Ministerstwo Edukacji Narodowej, Reforma systemu edukacji. Projekt, Warszawa (1998).

9. P. Długosz, Elitaryzm versus egalitaryzm systemu oświatowego. Analiza aspiracji edukacyjnych gimnazjalistów polski poludniowej. In M. Niezgoda (ed.), Społeczne skutkizmiany oświatowej w Polsce, Kraków: WUJ , pp. 129-132 (2011)

10. N. Stępień, Wyrównywanie szans edukacyjnych w warunkach polskiej szkoły po 1989 roku. O potrzebie polityki wyrównywania szans edukacyjnych, Studia Politicae Universitatis Silesiensis, T. 14, p. 128 (2015)

11. D. Zielińska, Jedynie wspólny front nauczycieli i rodziców może powstrzymać reforme edukacji. Available at: mediumpubliczne.pl. (2016)

12. Serwis Samorządowy PAP, Zmiany w szkole. MEN przypomina skutki nowelizacji systemu oświaty.

Available

at: http://samorzad.pap.pl/depesze/wiadomosci_centralne/160007 (2016) 
13. Komunikat Komisji Europejskiej, Wczesna edukacja i opieka nad dzieckiem: zagwarantujmy wszystkim dzieciom $w$ UE dobry start $w$ przyszłość. Brussels. Available at: https://eur-lex.europa.eu/legalcontent/pl/txt/?uri=celex\%3a52011dc0066 (2011)

14. M. Herbst, P. Strawinski, Early effects of an early start: Evidence from lowering the school starting age in Poland. Educational Research Institute. Available at: https://www.researchgate.net/publication/283355035_Early_effects_of_an_early_start _Evidence_from_lowering_the_school_starting_age_in_Poland (2015)

15. OECD, Education Policy Outlook: Poland. Available at: http://www.oecd.org/education/pol-country-profile.pdf (2015)

16. PISA, PISA - key findings for Poland. Available at: http://www.oecd.org/poland/pisa2015-poland.htm (2015)

17. K. McCann, Teenagers in the UK lag behind their peers in countries like Singapore, Japan and Poland in maths, science and reading, a major international report has found, The Telegraph. Available at: https://www.telegraph.co.uk/education/2016/12/06/uk-teenagers-lag-behind-peersmaths-science-reading-global-report/) (2016)

18. J. Suchecka, Polscy uczniowie znów wysoko w teście PISA. Ministerstwo Edukacji bagatelizuje ich sukces, Gazeta Wyborcza. Available at: http://wyborcza.pl/7,75398,21082119,polscy-uczniowie-znow-wysoko-w-tescie-pisaministerstwo-edukacji.html?disableRedirects=true (2016)

19. J. Przewłocka, Bezpieczeństwo uczniów i klimat społeczny w polskich szkołach. Raport z badania, Warszawa (2015)

20. Instytut Badań Edukacyjnych, Przemoc $w$ polskiej szkole. Available at: http://www.ibe.edu.pl/pl/publikacje/analizy-ibe/38-aktualnosci/525-przemoc-wpolskiej-szkole (2015)

21. A. Komendant-Brodowska, Przemoc w szkole. Raport z badań, Warszawa: Instytut Socjologii Uniwersytetu Warszawskiego (2011)

22. Muzeum Historii Polski. Plan Trzyletni. Available at: http://muzhp.pl/pl/e/1698/plantrzyletni) (2013).

23. Pyter M, Legal Principles of Functioning of Education in People's Republic of Poland, Studia Iuridica Lublinensia, XXIV, 4. (2015)

24. M. Zahorska, Successes and failures of the education reform, Przegląd Socjologiczny, 58, 3, pp. 119-142 (2009)

25. M. Sitek, Changes in educational inequalities in Poland. A polemic against the article of Zbigniew Sawiński. Gimnazja wobec nierówności społecznych, Edukacja, 2, 137, pp. 113-130 (2016)

26. L. F. Drucker, D. Horn, Decreased tracking, increased earning: Evidence from the comprehensive Polish educational reform of 1999, Budapest Working Papers On The Labour Market. BWP nr 2 (2016)

27. Edukacja i Wychowanie, Reforma edukacji: RPO żąda ujawnienia autorów podstawy programowej $z$ matematyki, Rzeczpospolita, Available at: http://www.rp.pl/Edukacja-i-wychowanie/304059964-Reforma-edukacji-RPO-zadaujawnienia-autorow-podstawy-programowej-z-matematyki.html (2018)

28. RPO, Rzecznik Praw Obywatelskich za ujawnieniem autorów nowej podstawy programowej z matematyki. Available at: https://www.rpo.gov.pl/pl/content/rpo-zaujawnieniem-autorow-nowej-podstawy-programowej-z-matematyki (2018)

29. Miliony za zmiany $w$ szkołach. Rzeczpospolita. Available at: http://www.rp.pl/Polityka/302229871-Miliony-za-zmiany-w-szkolach.html. (2018) 
30. Zwrot kosztów reformy edukacji. Available at: www.tvn24.pl/wiadomosci-zkraju,3/zwrot-kosztow-reformy-edukacji-i-remontow-szkol-tego-chcasamorzady,817456.html (2018) 